\title{
HUBUNGAN ANTARA DUKUNGAN SOSIAL DENGAN BURNOUT PADA PERAWAT PUTRI DI RUMAH SAKIT SWASTA
}

\author{
Taufik Nur Rohman \\ Nanik Prihartanti \\ Universitas Muhammadiyah Surakarta \\ Haryanto F. Rosyid \\ Universitas Gadjah Mada
}

\begin{abstract}
INTISARI
Tujuan penelitian ini ialah memeriksa hubungan antara dukungan sosial dan burnout of sebuah rumah sakit swasta of Surakarta, Jawa Tengah. Subjek penelitian terdiri atas 45 perawat putri di rumah sakit tersebut. Dua skala digunakan dalam penelitian in, yaitu: (1) skala dukungan sosjal dirancang untuk mengukur dukungan sosial, teroiri atas empat aspek: perhatian emosional, dukungan insirumental, penyediaan informasi, dar adanya penilaian. (2) skala burnout terdiri atas tiga aspek, yaitu: kelelahan fisik, kelelahan mental, dan kolelahan emosional. Hasil analisis produk momen menunjukkan adanya korelasi negatif dan signifikan antara dukungan sosial dan burnout d antara para perawat putri of rumah sakit swasta.
\end{abstract}

Kata kunci: dukungan sosial, burnout, perawat putri

Taufik Nur Rohman adalah alumnus Fakultas Psikologi UMS Surakarta oan saat ini bekeria sebagai staf perrgajar pada Fakultas Psikologi Universitas Persada indonesia YA Jakanta.

Nanik Prihartanti adalahalumnus Fakultas Psikologi UGM, baik program S. 1 maupun S-2. Saat ini bekerja sebagai dosen Fakultas Psikologi UMS dan tengah menempuh program S3 Program Siudi Psikologi di UGM.

Haryanto F. Rosyid adalah dosen Fakuhas Psikologi UGM.

\section{PENGANTAR}

$\mathrm{D}$ alam kehidupan yang semakin kompleks ini, orang selalu dituntut untuk menciptakan dan mencapai keserasian, serta kebahagiaan hidup bersama. Salah satu cara untuk dapat mencapai tujuan tersebut ialah aktivitas bekerja. Melalui kegiatan ini orang berusaha mengaktualisasikan keberadaan dirinya. Usaha-usaha orang untuk mencapai kebutuhan hidup, menciptakan kemajuan, meraih kesuksesan, dan perkembangan yang dialami mencerminkan kualitas sumber daya manusia. Sumber daya manusıa yang berkualitas baik akan senantiasa berusaha untuk mencapai 
keberhasilan seoptimal mungkin dan meningkatkan produktivitasnya.

Perawat ialah satu jenis profesi yang pada dewasa ini banyak dibutuhkan dan diusahakan peningkatan kualitas keprofesiannya. Tugas pokok seorang perawat ialah merawat pasien untuk mempercepat proses penyembuhan. Dalarn mengangani pasien rawat inap, misalnya, seorang perawat membutuhkan ketrampilan-ketrampilan tertentu yang sudah harus dikuasai sebelumnya. Gunarsa dan Gunarsa (1985) menyatakan perawat sebagai seor ang yang telah dipersiapkan melalui pendidikan untuk turut serta merawat dan menyembuhkan orang sakit, usaha-usaha rehabilitasi, pencegahan penyakit, yang dilaksanakan sendiri atau d bawah pengawasan dokter atau suster kepala. Dari sini nampak bahwa cakupan keja seorang perawat cukup luas, tidak hanya merawat tetapi sampai pada tindakan rehabilitasi, dan membutuhkan persyaratan-persyaratan tertentu.

Lebih lanjut Gunarsa dan Gunarsa (1985) menjelaskan bahwa seorang perawat karena pekerjaannya yang dinamis, perlu memiliki kondisi badan yang baik, sehat dan mempunyai energi yang banyak. Kondisi ba dan yang kurang menguntungkan akan berakibat perawat mudah pat ah semangat bilamana saat bekeja ia mengalami tekanan fisik mental, maupun emosional. Keletihan tubuh akan berpengarun negatil terhadap keputusan yang diambil dan kemampuan mengkonsentrasikan pada pekerjaannya. Seorang perawat yang mengalami kelelahan fisik cepat terganggu konsentrasi berfikirnya, sehingga ia tidak dapat memusatkan perhatian terhadap pekerjaan atau pasien yang sedang dihadapinya. Seorang perawat dalam melaksanakan pekerjaan tidak dapat menghindarkan diri dari adanya tekanan-tekanan ini. Kegagalan dalam menyelesaikan tekanan yang muncul akibat aktivitas kerja, mencakup tiga aspek, yaitu: tekanan fisik. mental, dan emosional (Gunarsa \& Gunarsa, 1985). Ketiga bentuk tekanan ini bilamana dibiarkan berlarut-larut tidak segera ditanggulangi akan menimbulkan gejala yang disebut burnout(Etzion, 1984).

Manusia sebagai makhluk sosial membutuhkan kehadiran manusia lain untuk berinteraksi. Walgito (1983) menyatakan bahwa hubungan antara individu dengan lingkung. annya terutama lingkungan sosial ternyata tidak berjalan searah, tetapi hubungan ini bersifat timbal balik. Lingkungan mempengaruhi individu, dan individu mempengaruhi perkembangan lingkungan.

Suasana kerja yang baik tercipta antara lain karena adanya dukungan sosial di ling. kungan tempat kerja. Sarason dkk (1983) mendelinisikan dukungan sosial sebagai suatu keadaan yang bermanfaat bagi individu yang diperoleh dari orang lain yang dapat dipercaya. Dari interaksi ini individu menjadi tahu bahwa orang lain memperhatikan, menghargai, dan mencintai dirinya.

Dalam pelaksanaan pengabdiannya pe rawat tidak hanya berhubungan dengan pasien saja, telapi juga berhubungan dan berinteraksi dengan keluarga pasien, teman pasien yang menengok, dan tentu saja dengan teman sekerja sesana perawat. Beban kerja yang demikian ini memungkinkan sekali profesi perawat menderita gejala psikologis yang disebut burnout.

\section{TELAAH PUSTAKA}

Jackson, Schwab, dan Schuler (1986) menyatakan bahwa istilah burnoutpertama kali diperkenalkan oleh Herbert Freudenberger pada tahun 1974.

Garden (1984) berpendapat bahwa bum out adalah suatu bentuk distress psikologis yang manifestasinya berupa suatu keadaan kehilangan energi dan kemerosotan kinerja. Meier (1984) menyatakan burnoutsebagai suatu keadaan menurunnya harapan untuk 
mendapatkan dukungan nilai kerja. Ahli lain, Firth dan Britton (1989), mengemukakan pengertian burnoutialah keadaan internal negatif, berupa pengalaman psikologis, biasanya menunjukkan kelelahan atau kehabisan tenaga dan motivasi untuk bekerja. Pines dan Aronson (dikutip Etzion, 1984) mendefinisikan burnout sebagai suatu keadaan individu yang mengalami kelelahan secara fisik, emosional, dan mental. Di sini dapat dikatakan bahwa burnout merupakan keadaan internal negatif dari seseorang yang ditandai dengan tiga gejala. yaitu: kelelahan fisik, emosional, dan mental.

Konsepsi burnouthanya dipergunakan dalam kaitannya dengan pekerjaan. Bahas. an-bahasan yang dilakukan para ahli mengenai gejala kelelahan terse but, tidak satu pun yang tidak dikaltkan dengan lingkungan dan jenis pekerjaan. Dengan kata lain, seseorang yang mengalami keadaan internal negatif tetapi tidak dikaitkan dengan pekerjaan, tidak dapat disebut mengalami burnoun, walaupun menunjukkan gejala-gejala yang hampir sama dengan geiala burnout. Watson dan Tregerthan (1984) menyatakan bahwa bumoutadalah bentuk kelelahan emosional yang disebabkan oleh pekerjaan yang banyak mengandung muatan emosional dan terjadi pada individu yang terlalu peka. Fith dan Britton (1989) menyatakan penyebab burnout lalah orang terekspos pad a st res pekerjaan yang berkepanjangan. Sementara Jackson dkk (1986) menyatakan burnout dapa: muncul disebabkan oleh pekerjaan yang diulang-ulang, monoton dan tidak variatif.

Etzion (1984) mengutarakan bahwa jika karyawan mengalami stres yang mengakibatkan penurunan kineria, kehilangan kemampuan untuk memecahkan masalah, dan tidak mampu lagi membua: keputusan, serta perilakunya tidak terarah. maka karyawan ini sedang mengalami burnout.
Luthan (1986) membedakan dua bentuk stres, yaitu eustress dan distress. Stres yang memberi akibat positif disebut eustress. Orang yang menderita eustressakan bergairah, bersemangat, dan kinerjanya meningkat. Sedang stres yang berdampak negatif disebut distress. Pada saat bekerja orang dituntut untuk bertanggung jawab secara emosional. Tanggung jaw ab yang besar dan di luar kemampuan individu untuk melaksanakannya akan menimbulkan distress yang pada gilirannya akan menimbulkan burnout.

Cunningham dkk (Russell \& Velsen, 1987) menandaskan bahwa gejala-gejala bumoutmuncul dalam bentuk kelelahan fisik (dengan keluhan sakit kepala, radang pencernaan), kelelahan psikologis (depresi. sering marah), keluhan perilaku (kinerja menurun, sering mangkir dari pekerjaan). Hal yang sama dikemukakan oleh Pines dan Aronson (Etzion, 1984) mengenai gejala-gejala burnout yang meliputi: gejala fisik (kelelahan, merasakan adanya anggota badan yang sakit); gejala mental (merasa tidak mampu membuat keputusan, perasaan tertolak, tidak miampu memberikan sumbangan gagasan; gejala emosi (emosi lidak stabil, mudah tersinggung, atau terlalu peka, nglokro (bahasa Jawa).

Meier (1984) menjelaskan perbedaan antara burnoutdan depresi yang menyangkut rentang waktu penguat (reinforcement) dan keseringan dari penguat (rate of reinforcernent).

Manusia sebagai makhluk sosial, keberadaannya selalu membutuhkan dan dibutuhkan orang lakn. Interaksi timbal balik ini pada akhimya akan menciptakan hubungan ketergantungan satu sama lain. Kehadiran orang lain di clalam kehidupan pribadi seseorang begitu diperlukan. Hassan (1974) menyatakan bukannya Cogito Ergo Sum melainkan Respondeo Ergo Sum. Kehadiran orang kain di dalam kehidupan pribadi 
seseorang tidak bersifat "dengan" sesarra, melainkan "bersama" sesama. Hal ini tejadi karena seseorang tidak mungkin memenuhi kebutuhan fisik maupun psikologisnya secara sendirian. Individu membutuhkan dukungan, terutama dari orang-orang terdekat. Sears, Freedman, dan Peplau (1991) ber. pendapat bahwa penampilan kerja yang lebih baik bila disertai kehadiran orang lain disebut dukungan sosial.

House (Etzion, 1984) menyatakan, dukungan sosial sebagai suatu bentuk transaksi antar pribadi yang melibatkan perhatian emosional, bantuan instrumental, pemberian informasi, dan adanya penilaian. Sarason dkk (1983) mengemukakan dukungan sosial sebagai suatu keadaan yang bermanfaat bagi individu yang diperoleh dari orang lain yang dapat dipercaya. Sementara Ganster dkk (1986) mengatakan dukungan sosial merupakan hubungan yang membantu dan berkualitas. Lebih jauh Cohen dan Syme (1985) dan House (Etzion, 1984) memperinci empat aspek dukungan sosial. yaitu: (1) Emosional. Individu membutuhkan empati. Bilamana seseorang dapat menghargai, mempercayai, dan mengerti dirinya lebih baik, ia akan menjadi terbuka terhadap aspek-aspek baru dari pengalaman hidupnya. Rogers (1987) mengermukakan, jika individu diterima dan dihargai secara positif oleh orang-orang lain, individu tersebut akan cenderung untuk mengembangkan sikap posit if terhadap diri sendiri, dan lebih menerima dan menghargai dirinya. (2) Peralatan. Penyediaan piranti guna menunjang kelancaran kerja, secara langsung akan meringankan beban yang ditanggung seseorang. Hal ini meliputi bantuan suatu benda, membantu pelaksanaan pekerjaan, termasuk di dalamnya memberi peluang waktu. (3) Informasi. Pemberian informasi, maksudnya agar informasi dapat digunakan untuk mengatasi masalah pribadi maupun masalah pekerjaan. Informasi ini mencakup perrberian na- sihat, pengarahan, keter angan-keterangan yang dibutuhkan. Penggunaan informasi berarti menyampaikan informasi yang dimilki kepada orang lain yang membutuhkan. (4) Penilaian. Penilaian meliputi dukungan pekerjaan, prestasi, dan peran sosial yang terdiri atas umpan balik, perbandingan sosial, dan afirmasi (persetujuan, menyatakan "ya"). Rogers (1987) menyatakan setiap manusia merrpunyai kebutuhan akan kehangatan, penghargaan, dan penerimaan, pengagungan, dan cinta dari orang lain. Oieh Rogers keseluruhan ini disebut need for positive regard.

Bagi karyawan, pemberian penilaian positif akan menungkatkan kepercayaan diri bahwa dirinya marripu menghadapi tuntutan pekerjaan. Berdasar beberapa uraian d atas. dapat ditarik suatu pengertian bahwa dukungan sosial ialah: hubungan an tar pribadi yang bersifat membantu, menolong yang diperoleh dari orang lain yang dapat dipercaya. Hubungan ini melibatkan empat aspek. yaitu: aspek emosional, peralatan, pemberian informasi, dan penilaian.

Sumber-sumber dukungan sosial menurut Ganster, Fusilier, dan Mayes (1986) ada tiga, yaitu: keluarga, rekan sekerja, dan supervisor (penyelia). Keluarga merupakan tempat pertumbuhan dan perkembangan seseorang, kebutuhan-kebutuhan fisik dan psikis mula-rrula terpenuhi dari lingkungan keluarga. Sehingga keluarga termasuk kelom. pok yangterdekat dengan individu. Individu sebagai anggota keluarga akan menjadikan keluarga sebagai tumpuan harapan, tempat bercerita. tempat bertanya. dan tempat mengeluarkan keluhan-keluhan bilamana individu sedang menghadapi permasalahan. Kondisi ini mengisyaratkan bahwa keluarga dapat menjadi surnber dukungan sosial bagi anggota yang tengah menghadapi persoalan-persoalan di tempat kerja. Sanmustari (1988) menjelaskan, pad a dasarnya manusia adalah makhluk sosial yang membutuh- 
kan penghargaan dalam hubungannya dengan orang lain. Dalam kerja, manusia membutuhkan penghargaan atas apa yang sudah mereka kerjakan. Manusia yang sehat kondisinya akan merasakan dirinya berguna, penting, dan membutuhkan penghargaan sesuai martabatnya sebagai manusia. La Rocco dan Jones (1978) berpendapat bahwa karyawan yang bekerja membutuhkan dorongan moral dari rekan sekerja maupun atasannya. Dorongan mora! dari atasan antara lain tuntutan atasan untuk mencapai sasaran kerja melalui jadwal dan perencanaan kerja, hubungan antar pribadi, dorongan moral pribadi, kesediaan atasan untuk mendengarkan masałah-masalah pribadi karyawan. maupun masalah-masalah yang berkaitart dengan pekerjaan. Sedang bentuk dorongan moral dari reken sekerja, meliputi: kualitas hubungan kerja sama, kehangatan berteman den rasasaling mempercayai, serta kebanggaan menjadi anggota satu kelompok. Sumber dukungan sosial ketiga berasal dari penyelia. As'ad (1988) mengemukakan bahwa seorang penyelia ialah seorang manajer yang bertanggung jawab kepada manajer yang lebih tinggi kedudukannya. Tugas utama penyelia ialah memimpin pekerja pelak. sana dalam taraf operasional. Kedudukan penyelia berada di antara pihak manajemen dengan pihak pekerja. Pad a diri penyelia selain dituntut kemampuan teknis untuk melaksanakan pekerjaan, juga kemampuan hubungan antar pribadi. Hal ini ditunjukkan dengan kemampuan mendekati bawahan, mengerti apa yang dipikirkan, dirasakan, dan dikehendaki oleh bawahan, sehingga bawahan bekerja dengan sikap positif. Penyelia yang efektif harus tahu dan menyenangi para anggotanya, serta dapat membuat para bawahan merasa sebagai orang yang dibutuhkan, diperlukan, dan dapat memuaskan kebutuhan individual mereka. Smith (1984) menyatakan bahwa penyelia yang mendukung, menerima, dan menyukai, serta me- ngerti bawahan, biasanya merestui kegiatan bawahannya dan tertartik untuk memenuhi kebutuhan-kebutuhan karyawannya.

Zajonc (Sears, 1985) berpendapat bahwa berada di tengah orang lain akan meningkatkan motivasi seseorang. Ketiadaan hubungan yang saling membantu antar karyawan, dan antiara sumber-sumberdukungan sosial akan menyebabkan karyawan gugup, merasa kacas, tidak tahu apa yang harus dilakukan, tidak siap melakukan sesuatu, tidak mampu memberikan pertolongan dan bantuan kepada rekan sekerja yang membutuhkan pertolongan, gelisah, bersikap oposisi, tidak perduli pada kemampuan dirinya sendiri, dan lidak tahu usul-usul apa yang harus di ketengahkan (Smith, 1984). Selanjutnya dikemukakan bahwa hubungan supportive dari penyelia bukan hanya sekedar basa-basi, tetapi membutuhkan keakraban dan perhatian kepada karyawan dan keluarganya. Ketiadaan dukungan sosial akan berpengaruh negatif terhadap tenaga kerja maupun organisasi tempat bekerja.

Kanner dkk (Etzion,1984) mengemukakan bahwa dukungan sosial secara langsung berhubungan dengan burnout. Russell dan Velsen (1987) meneliti hubungan job stressdengan bur noutdi kalangan guru sekolah. Mereka menemukan bahwa guru-guru yang mendapatkan dukungan sosial dari para penyelia alau atasan mereka secara berurang kali merasakan berkurangnya kelelahan emosional, guru-guru menjadi bersikap lebih positif terhadap peker jaan, siswa-siswanya, dan semakin meningkat prestasí kerjanya. Penelitian lain mendapatkan bahwa para perawat yang memperolah dukungan sosial dari para penyelianya menúnjukkan pengaruh positif terhadap kesehatan fisik dan kesehatan mentalnya (Constable \& Riussell, 1986). Hal serupa juga diperoleh dari penelitian House yang mengambil sampel penelitian para pekerja d pabrik (Russell \& Velsen, 1987). Penelitian yang dilakukan 
Etzion (1984) terhadap para manajer dan pekerja sosial di Israel menunjukkan bahwa para manajer dan pekerja sosial yang mendapatkan dukungan dari keluarganya menunjukkan gejala-gejala menderita burnout yang lebih rendah dibandingkan dengan subjek yang tidak memperoleh dukungan sosial.

Di rumah sakit, seorang perawat diharapkan mendapat dukungan sosial yang berasal dari keluarga, rekan sekerja, dan penyelia. Bentuk dukungan sosial dapat berupa kesempatan untuk bercerita, meminta pertimbangan, bantuan, nasihat, atau bahkan mengeluh bilamana sedang menghadapi persoalan pribadi atau peker jaan. Seorang perawat di dalam kerjanya akan mengembangkan perasaan diperlukan, dicintai, dimanusiakan keberadaannya dan ditolong oleh sumber-sumberdukungan sosial tersebut, sehingga dapat melaksanakan pekerjaan dengan baik. Bilamana hubungan ini terjadi maka perawat dapat menjalankan tugasnya dengan lebih baik, dan performancenya meningkat. Akan tetapi bilamana perawat tidak memperoleh dukungan sosial, maka ia akan merasa resah, mengalami kebingungan, merasa tidak mempunyai sandaran untuk mengadukan permasalahannya. Keadaan yang demikian tentu akan berdampak negatif pada para perawat, darı akan tercermin pada kinerja rumah sakit yang tidak memuaskan.

\section{HIPOTESIS}

Hipotesis yang diajukan dalam penelitian ini ialah: terdapat hubungan negatif antara dukungan sosial dengan burnout. Semakin tinggi dukungan sosial yang dirasakan oleh para perawat, maka akan semakin rendah gejala burnoutyang ditunjukkannya.

\section{METODE}

Penelitian ini menggunakan dua buah alat ukur. Alat ukur pertama ialah skala du- kungan sosial. Alat ini disusun berdasarkan aspek-aspek dukungan sosial yang dirumuskan oleh House (Etzlon, 1984; Cohen \& Syme, 1985). House menyatakan terdapat empat aspek dukungan sosial, yaitu: perhatian emosional, bantuan instrumental, pemberian informasi, dan adanya penitaian. Berpedoman pada empat aspek tersebut, dan tiga sumber dukungan sosial yang dikemukakan oleh Ganster dkk. (1986) peneliti mengembangkan skala dukungan sosial. Sumber-sumber dukungan sosial yang dimaksud ialah keluarga, rekan sekerja, dan penyelia. Skala dukungan sosiał yang semula tersusun atas 120 butir, ternyata setelah diuji coba pada 40 orang perawat, menghasilkan 83 butir sahih.

Indeks diskriminan yang menunjukkan korelasi skor aitem dengan skortotal skala bergerak antara $r_{p a}=0,236$ sampai dengan $r_{p q}=0,794 ; p / 0,05$. Sedang reliabilitas skala menurut analisis varians yang dikembangkan oleh Hoyt, $\mathrm{rth}^{\text {rt }}=0,971$.

Alat ukur kedua yang digunakan dalam penelitian ini ialah skala burnout. Skala ini disusun berdasar pada faktor-faktor burnout yang dikemukakan oleh Pines dan Aronson (Etzion, 1984). Dalam pembuatan butir-butir skala burnout peneliti mengacu pada model yang dikembangkan ofeh Prawitasari (1988) untuk faktor-kelelahan fisik, dan oleh Burns (1988) untuk faktor-faktor kelelahan emosional dan mental. Dari 60 butir, setelah ujicoba dengan menggunakan subjek yang sama dengan subjek pengembangan skala dukungan sosial, maka diperoleh 42 butir yang sahih. Koetisien diskriminan butir yang sahih bergerak dari $r_{p q}=0,260$ sampai dengan $r_{p q}=0,655 ; p / 0,05$. Indeks reliabilitas dengan menggunakan teknik Hoyt diperoleh $r^{\prime \prime}=0,894$.

Subjek penelitian ini ialah perawat putri yang bekerja di sebuah rumah sakit swasta di Surakarta, Jawa Tengah. Cikal bakal rumah sakit ini ialah sebuah Balai Pengobat- 
an yang didirikan pada tahun 1936. Perkembangan dan peningkatan kualitas yang senantiasa diusahakan oleh para pengurusnya membuahkan Surat Keputusan dari Direktur Jendral Pelayanan Medik, Departemen Kesehatan untuk mengubah status dari poliklinik menjadi sebuah rumah sakit. Perubahan status ini berlaku sejak tahun 1986.

Rumah sakit ini mempekerjakan perawat putri sebanyak 106 orang, di samping perawat putra yang juga bertugas melayani kebutuhan para pasien.

Peneliti menyebarkan skala dukungan sosial dan skala burnout kepada 50 orang perawat secara random. Setelah kedua skala terkumpul kembali, diketahui terdapat lima set skala yang tidak dapat diikutkan di dalam analisis data. Hal ini disebabkan karena pengisiannya tidak lengkap, sehingga hanya sejumlah 45 set data yang menjadi subyek penelitian.

\section{HASIL}

Hasil perhitungan statistik dengan teknik korelasi product mornentdiperoleh koefisien korelasi antara dukungan sosial dan burnoutsebesar $r_{x y}=-0,734 ; p / 0,001$.

Tabel 1

Skor Maksimum dan Minimum pada Dua Variabel

\begin{tabular}{|l|c|c|c|c|}
\hline Variabel & $\begin{array}{c}\text { Skor } \\
\text { Maksimum }\end{array}$ & $\begin{array}{r}\text { Skor } \\
\text { Minimum }\end{array}$ & Mean & SD \\
\hline \hline Dukungan Sosial & $\begin{array}{l}278 \\
\text { Burnout }\end{array}$ & $\begin{aligned} 195 \\
104\end{aligned}$ & $\begin{array}{r}249,933 \\
81,600\end{array}$ & $\begin{array}{r}21,64 \\
9,66\end{array}$ \\
\hline
\end{tabular}

\section{PEMBAHASAN}

Hașil penelitian ini menunjukkan bahwa ada hubungan negatif antara dukungan sosial dengan burnout. Hal ini berarti hipotesis yang diajukan diterima kebenarannya.

Dukungan sosial merupakan hubungan yang membantu, bermanfaat, dan diperoleh dari orang-orang terdekat. yaitu keluarga, rekan sekerja, dan penyelia. Dukungan sosial. menurut House (Etzion, 1984), mencakup empat aspek: aspek perhatian emosional, aspek peralatan, aspek pemberian informasi, dan aspek penilaian. Dengan bantuan em pat aspek yang diper oleh dari orang lain seseorang dapat mengatasi masalah- masalah psikologis dengan cepat dan tepat. Dukungan sosial merupakan bekal bagi seseorang unfuk menghadapi kesulitan sehingga tidak mengalami burnoul.

Burnout merupakan keadaan internal negatif yang ditandai dengan tiga simtom: simtom fisik, emosional, dan mental. Burnoutterjadi pada situasi yang menuntut seseorang untuk bertanggung jawab secara emosional terhadap pekerjaannya.

Seorang perawat yang bekeria di rumah sakit atau merawat pasien, akan berhubungan langsung dengan pasien dalam rangka membantu mempercepat proses penyembuhan. Keberhasilan seorang perawat 
dalam mernbangun hubungan yang baik dengan pasien, sangat ditentukan oleh kemampuannya berhubungan, berinteraksi dengan pasien. Kegagalan perawat dalam membina hubungan yang baik, menyebabkan pasien merasa kurang diperhatikan. Dari sebab itu, seorang perawat dituntut untuk peka dan mencurahkan seluruh perhatiannya terhadap setiap perubahan yang terjadi pad a diri pasien sehingga pada akhimya seorang perawat memperoleh kepercayaan dari pasien yang dirawatnya.

Dalam pengabdiannya, seorang perawa: tidak dapat memilih-milih pasien yang dirawatnya. Di rumah sakit seorang perawat sudah ditugaskan pada ruang tertentu, di mana ia tidak dapat memesan sebelumnya. Sela in pasien yang dilayani mengidap penyakit yang berbeda-beda, mereka juga berasal dari pelbagai latar belakang sosial ekonomi, usia, dan pendidikan. Dalam melayani seorang pasien yang akan dirawatnya, mereka selalu memikirkan sejenak "orang" macam apakah pasien inı.

Beban pekerjaan yang dipaparkan di atas, membuktikan bahwa pekerjaan seorang perawat sangatlah berat. Di satu sisi seorang perawat harus menjalankan tugas yang menyangkut kelangsungan hidup seseorang, di sisi lain keadaan psikologis perawat sendiri juga harus tetap terjaga. Kondisi seperti inilah yang seringkali mendukung munculnya burnout.

Pada dasarnya manusia mengada bukan "dengan" sesama, melainkan "bersama" sesama. D sini "keakuan" berubah berganti menjadi "kekitaan". Dalam keadaan seperti ini, seseorang yang menghadapi problem psikologis akan memperoleh ternan untuk berbagi rasa. Diharapkan, kebersamaan bersama sesama ini menjadi jalur buat pelepasan emosi sehingga ketegangan-ketegangan yang ada bisa mengendor dan tidak menggarıggu kehidupan kejiwaan seseorang.
Dibuktikannya hipotesis dengan hasi penelitian ini, berarti mendukung hasil penelitian yang dilakukan oleh Etzion (1984) dan Russeli dan Velsen (1987) bahwa dukungan sosial secara langsung berhubungan dengan burnout.

\section{PENUTUP}

Simpulan dari penelitian ini adalah terdapat hubungan negatif antara dukungan sosial dengan bumoutpada perawat putri. Semakin tinggi dukungan sosial semakin rendah gejala burnout yang diatami. Semakin rendah dukungan sosial, maka semakin tinggi bumout.

Masalah burnout masih belum banyak diteliti di Indonesia. Sebenarnya bukan hanya di Indonesia tetapi di dunia ilmu Psikologi, masalah ini masih bersifat embrionik. sebagaimana dikemukakan oleh Jackson, dkk. (1986). Mengingat sifatnya yang masih belum begitu jelas sosoknya, maka sangat dapat dimengerti bilamana penelitian mengenai burnout masih perlu terus diusahakan. Ј

\section{KEPUSTAKAAN}

As'ad, M. 1986. Kepemimpinan dalam Organisasi Perusahaan. Makalah. Lokakarya Kohesivitas. Yogyakarta: Fakultas Psikologi Universitas Gadjah Mada.

Burns, M.D. 1988. Terapi Kognitif: Pendekatan Baru bagi Penanganan Depresi. (Terjemahan). Jakarta. Erlangga.

Cohen, S. and Syme, S.L. 1985. Social Support and Health. London. Acadernic Press inc.

Etzion, D. 1984. Moderating Effect of Social Support on the Stress-Bumout Relationship. Journal of Applied Psychology. 69. 615-621. 
Firth, H. and Britton, P. 1989. "Burnout", Absence and Turn-over amongst British Nursing Staff. Journal of Occupational Psychology. 62. 55-59.

Fusilier, M.R. Ganster, D.C., Mayes, B.T. 1986. The Social Support and Health Relationship: Is There a Gender Differences? Journal of Occupational Psychology. 59. 145-153.

Ganster, D.C. Fusilier, M.R., Mayes, B.T. 1986. Role of Social Support in The Experience of Stress at Work.Journal of Applied Psychology. 71. 102-110.

Garden, A.M. 1989. Burnout: The Effect of Psychological Type on Research Findings. Journal a Occupational Psychotogy 62. 223-234.

Gunarsa, S.D. dan Gunarsa, M. 1989. Psikologi Perawatan. Jakarta: BPK Gunung Agung.

Hassan, F. 1974. Kita dan Kami. Jakarta: Bulan Bintang.

Jackson, S.E. Schwab, R.L. Schuler, R.S. 1986. Toward an Understanding of the Burnout Phenomenon. Journal of Applied Psychology 71. 4. 630-640.

La Rocco. J.M. and Jones, A.P. 1987. Coworker and Leader Support as a Moderators of Stress-Strain Relationship in Work Situation. Journal of Applied Psychology, 63. 5. 629-634.

Meier, S.T. 1984. The Construct Validity of Burnout. Journal of Occupational Psy- chology 57. 211-219.

Prawitasari, J.E. 1988. Laporan Singkat. Validitas Eksternal Skala Kelelahan Fisik. Jurnal Psikologi. Juli. XVI.1.

Rogers, C.R. 1987. Antara Engkau dan Aku. (Terjemahan Agus C). Jakarta. Gramedia.

Russell, D.W, Van Velsen, D. Altmeier, E 1987. Job Related, Social Support and Burnout Among Classroom Teachers. Journal of Applied Psychology. 72.2.269-274.

Sanmustari, R.B. 1987. Manusia dalam Industri dan Organisasi. Makalah. Kursus Manajemen Keuangan PJKA-PPM FE UGM.

Sarason, I.G. Levine, H.M. Basham, R.B. Sarason, B,R. 1983. Assessing Social Support: The Social Support Questionaire. Journal of Personality and Social Psychology. 44.T.127-139.

Sears, D.O. Freedman, J.L. Peplau, L.A. 1991. Social Psychology (Teriemanan Adryanto). Jakarta: Erlangga.

Smith, H.C. 1964. Psychology of industrial Behaviour. New York: McGraw-Hill Inc.

Walgito, B. 1983. Psikologi Sosial. Yogyakarta. Yayasan Penerbit Fakultas Psikologi Universitas Gadjah Mada.

Watson, D.L. and Tregerthan, G.B. 1984. Social Psychology: Science and Application. Illinois: Scott, Foresman and Company. 